\title{
Pengaruh Rasio Regangan Terhadap Perilaku Low Cycle Fatigue (LCF) Paduan Al 7075-T7
}

\author{
Ari Beni Santoso ${ }^{1 *}$, Mohammad Badaruddin ${ }^{2}$, Shirley Savetlana ${ }^{2}$ \\ ${ }^{1}$ SMK Negeri 1 Seputih Agung, Jl. Raya Dono Arum, Kecamatan Seputih Agung, \\ Kabupaten Lampung Tengah, Lampung. \\ ${ }^{2}$ Jurusan Teknik Mesin, Fakultas Teknik, Universitas Lampung, \\ Jalan Profesor Soemantri Brojonegoro No. 1, Bandar Lampung 35143. \\ Email. aribenisantoso@gmail.com
}

\begin{abstract}
The aluminium 7075 alloy is widely used in the aircraft industry for components on the front spar, stabilizer, frames that requires a high strength and low density ratio.The aerospace and automotive industries need to design for lightweight materials, where aluminum alloys are often used as the main component.Aluminum alloyshave good corrosion resistance properties. This material is used in a wide field not only for household appliances but also for industrial purposes, for example air-craft, car, marine and other constructions. The phenomenon of ductility decreasing due to pre-fatigue deformation, is the most significant for the combination of long pre-fatigue time, high humidity, and low strain rate.The process of making specimen shapes and dimensions were prepared according to ASTM E8 standard for the tensile specimens and ASTM E606 standardfor LCF test, respectively. Characterization of changes in material structures and the types of failure that occuredwerecarried out using OM, SEM and EDX.

The aluminiumalloy 7075-T7 were systematically fatigued under low cycle fatigue testing with strain ratio $(R)=-1,-0.05,0.05$, and 0.5, strain rate $=4 \times 10^{-3} / \mathrm{s}$, and strain amplitude $=0.006 \mathrm{~mm} / \mathrm{mm}, 0.008$ $\mathrm{mm} / \mathrm{mm}, 0.010 \mathrm{~mm} / \mathrm{mm}, 0.012 \mathrm{~mm} / \mathrm{mm}, 0.014 \mathrm{~mm} / \mathrm{mm}$ and $0.016 \mathrm{~mm} / \mathrm{mm}$. Aluminum alloys show continuous stability for failure cycle, and the highest material life (fatigue life) is found for strain ratio $=0.05$ with strain amplitude $=0.016 \mathrm{~mm} / \mathrm{mm}$ while the lowest fatigue life is for strain ratio $=-0.05$ with strain amplitude $=0.006$ $\mathrm{mm} / \mathrm{mm}$, in which the material show continuous cyclic hardening of the first failed cycle.
\end{abstract}

\begin{abstract}
Abstrak
Paduan aluminium 7075 banyak digunakan di industri pesawat terbang untuk komponen pada spar depan, stabilizer, frame yang membutuhkan ragam kekuatan tinggi dan rasio kepadatan rendah. Industri kedirgantaraan dan otomotif perlu merancang material ringan, dimana paduan aluminium sering digunakan sebagai Komponen utama.Aluminum paduan memiliki sifat tahan korosi yang baik. Bahan ini digunakan di lapangan yang luas tidak hanya untuk peralatan rumah tangga tetapi juga untuk keperluan industri, misalnya konstruksi pesawat terbang, mobil, kelautan dan konstruksi lainnya. Fenomena daktilitas menurun karena deformasi pra-kelelahan, adalah yang paling signifikan untuk Kombinasi waktu pra-kelelahan yang lama, kelembaban tinggi, dan laju regangan yang rendah. Proses pembuatan bentuk dan dimensi spesimen disiapkan sesuai standar ASTM E8 untuk spesimen tarik dan standar ASTM E606 untuk uji LCF. Karakterisasi perubahan struktur material dan jenis kegagalan yang terjadi pada penggunaan OM, SEM dan EDX.

Paduan aluminium 7075-T7 mengalami kelelahan secara sistematis pada pengujian kelelahan siklus rendah dengan rasio regangan $(R)=-1,-0.05,0.05$, and 0.5 , laju regangan $=4 \times 10-3 / \mathrm{s}$, dan amplitudo regangan $=0,006 \mathrm{~mm} / \mathrm{mm}, 0,008 \mathrm{~mm} / \mathrm{mm}, 0,010 \mathrm{~mm} / \mathrm{mm}, 0,012 \mathrm{~mm} / \mathrm{mm}, 0,014 \mathrm{~mm} / \mathrm{mm}$ dan 0,016 mm / mm. Paduan alumunium menunjukkan stabilitas kontinu untuk siklus kegagalan, dan umur material tertinggi (umur kelelahan) ditemukan pada rasio regangan $=0,05$ dengan amplitudo regangan $=0,016 \mathrm{~mm} / \mathrm{mm}$ sedangkan umur kelelahan terendah adalah rasio regangan = -0,05 dengan amplitudo regangan =0,006 Mm / mm, di mana material menunjukkan pengerasan siklik siklis pada siklus gagal pertama.
\end{abstract}

Kata kunci: Low Cycle Fatigue, Aluminum, Fatigue Life, cyclic, Strain Rate and Amplitude Regangan. 


\section{PENDAHULUAN}

Paduan aluminium sekarang ini banyak sekali digunakan sebagai bahan konstruksi karena memiliki sifat yang luar biasa yang memungkinkan unsur Aluminium mempunyai banyak kegunaan untuk aplikasi dalam berbagai bidang. Memiliki penampilan berwarna putih keperakan dan sifat kekuatan tinggi, spesifik gravitasi rendah, mampu cor tinggi, ketahanan aus tinggi, termal ekspansi rendah dan ketahanan korosi tinggi membuat Alumunium memiliki aplikasi luas dalam domain yang berbeda, seperti transportasi, dekorasi rumah dan aksesoris, bangunan dan konstruksi bankan untuk industri pesawat terbang [Zu dkk.,2008]. Paduan Al 7075 lebih sering digunakan untuk mengurangi berat bobot material namun tetap mempertahankan kekuatan getasnya, dan ada beberapa konsekuensi yang tak terduga dalam aplikasi yang melibatkan paparan panas untuk suhu tinggi. Bahkan, efek paparan suhu tinggi mendekati kondisi anil pada perilaku kelelahan paduan $\mathrm{Al}$ 7075-T651 belum diteliti secara langsung. Namun, efek anil pada monotonik dan anisotropi pada $400^{\circ} \mathrm{C}$ selama 5 menit yang sudah dilakukanpada paduan Al-7075 menghasilkan karakteristik dan anisotropi yang berbeda [Song dkk., 2011]. Karakterasasi perubahan struktur material dan jenis patahan yang terjadi dilakukan dengan melakukan pengujian OM, SEM serta EDX.

\section{MATERIAL, PERALATAN DAN METODE PENGUJIAN}

Material yang digunakan dalam penelitian ini adalah paduan aluminium AL $7075 \mathrm{~T} 7$ dengan Komposisi dasar $\mathrm{Si} \sim 0,510 \%, \mathrm{Cu} \sim 0.0104 \%, \mathrm{Fe} \sim$

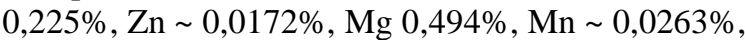
dan $\mathrm{Cr} \sim 0,023 \%$, Ti 0,0172\%, dan $\mathrm{Al} \sim 98.6 \%$. Bentuk dan dimensi ukuran spesimen uji tarik disiapkan sesuai standar ASTM E8 [ASTM E8, 2004] dan untuk uji LCF menggunakan standar ASTM E606 [ASTME 606, 2004] seperti gambar 1 dan 2. Proses pemesinan pembuatan spesimen menggunakan CNC EMCOTronic TM02 buatan Austria, dikerjakan di P2TK/VEDC Malang-Jawa Timur. Diameter grip spesimen adalah $12 \mathrm{~mm}$ untuk uji tarik dan LCF. Total 3 spesimen uji dibuat untuk uji tarik sedangkan specimen untuk LCF dibuat 30 spesimen.

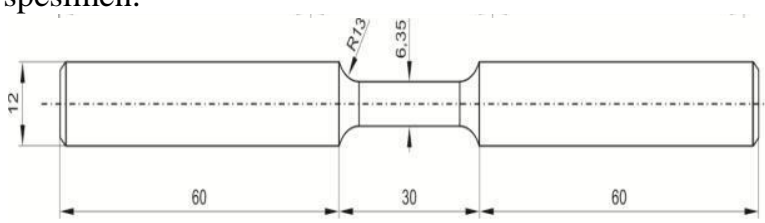

Gambar 1. Dimensi uji tarik ASTM E8

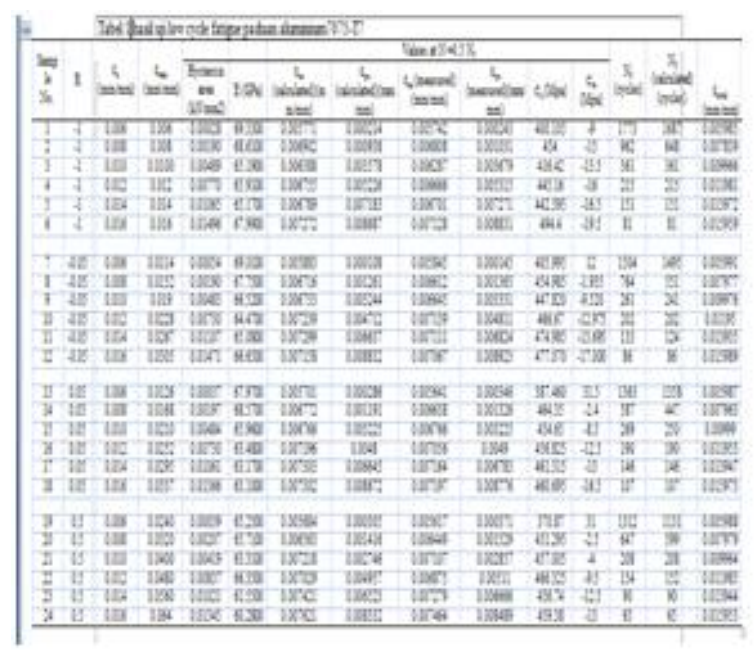

Gambar 2. Dimensi uji fatigue ASTM E606

\section{Peralatan Pengujian dan Metode Pengujian}

Untuk pengujian Tarik dan LCF, semua specimen uji yang sudah dibuat sesuai standar, diuji menggunakan mesin MTS Landmark $100 \mathrm{KN}$ (statik dan dinamik). Pada penelitian ini, untuk menentukan sifat mekanik paduan Al-Si-Fe-Mg-Ti pengujian dilakukan dalan dua grup: yaitu pengujian LCF dan pengujian tarik pada kondisi temperatur ruang.

\section{Pengujian low cycle fatigue}

Spesimen bentuk silinder panjang total 150 dengan diameter reduksi $6.5 \mathrm{~mm}$ dan gage length 13 $\mathrm{mm}$ paling sedikit 38 spesimen digunakan untuk uji LCF pada temperatur ruang $\left( \pm 25^{\circ} \mathrm{C}\right)$. Masingmasing pengujian dilakukan setiap satu parameter uji sebanyak lima spesimen. Extensometer model 632.13F-20 dengan gage length $10 \mathrm{~mm}$ dan mempunyai kemampuan mengontrol regangan $\pm 15 \%$ (tarik-tekan) dipasangkan pada daerah gage length spesimen. Pengujian low cycle fatigue dilakukan menggunakan MTS Landmark $100 \mathrm{KN}$ dengan kondisi rasio regangan $\mathrm{R}=-1,-0.05,0.05$, dan 0.5 laju regangan $4 \times 10^{-3} \mathrm{~s}$ dengan variasi amplitudo regangan $0.6 \%, 0.8 \%, 1.0 \%, 1.2 \%, 1.4 \%$, dan $1.6 \%$. Kurva hysteresis loops ( $\sigma$ vs. $\varepsilon$ ) dan kurva beban vs jumlah siklus secara otomatis direkam selama pengujian menggunakan program MTS Testsuite sebagai data-data kuantitatif untuk menentukan sifat fatigue paduan Al-Si-Mg-Ti. Semua data yang diperoleh dari hasil uji LCF dianalisis menggunakan softwere MTS Fatigue Analyzer (berlisensi).

Observasi mikrostruktur dan fraktografibservasi mikrostruktur dan fraktografi dilakukan untuk mengetahui perubahan struktur mikro karena pembentukan presipitasi elemen $\mathrm{Si}$, $\mathrm{Mg}$ dan Ti menggunakan optical microscopy (OM) 
and scanning electron microscopy (SEM). Begitu juga karakterisasi menggunakan EDS dilakukan untuk mempelajari perubahan fasa-fasa. Semua data kuantitatif dan kualitatif dari hasil OM, SEM dan EDS digunakan untuk mempelajari perilaku LCF melalui perubahan mikrostruktur dan perubahan fasa dalam paduan aluminium selama pengujian LCF.

\section{Pengujian terhadap ketahanan uji tarik}

Pengujian tarik pada temperatur ruang dilakukan paling sebanyak tiga spesimen. Selama pengujian tarik, kontrol pergerakan aktuator secara aksial pertama menggunakan laju regangan konstan $0.3 \% /$ min untuk menentukan modulus elastisitas dan tegangan luluh $(0.2 \%$ offset $)$. Setelah spesimen mencapai regangan $0.3 \%$, kontrol aktuator secara otomatis dipindah ke kontrol perpindahan dengan laju $0.15 \mathrm{~mm} / \mathrm{min}$ [ASTM E8, 2004]. Pengujian dilakukan sampai spesimen patah. Data tegangan luluh, modulus elastisitas, keuletan dan tegangan maksimum akan diperoleh. Nilai regangan plastis yang diperoleh dari kurva teggangan vs regangan digunakan sebagai nilai referensi untuk parameter pengujian LCF.

\section{HASIL DAN PEMBAHASAN}

\section{Hasil uji laju kelelahan siklus rendah}

Tabel 1 menunjukkan daftar hasil pengujian low cycle fatigue yang menunjukkan jumlah siklus kegagalan pada setiap laju regangan terhadap amplitudo regangan yang berbeda. Respon perilaku tegangan siklik menunjukkan pengaruh amplitudo regangan dan laju regangan terhadap jumlah siklus kegagalan pada pengujian LCF. Gambar 3. pengaruh yang signifikan pada variasi puncak tegangan tarik vs jumlah siklus uji low cycle fatigue adapun variasi laju regangan yang digunakan ialah 0,004/s terhadap amplitudo regangan $0,006 \mathrm{~mm} / \mathrm{mm} ; 0,008 \mathrm{~mm} / \mathrm{mm}$; $0,010 \mathrm{~mm} / \mathrm{mm} ; 0,012 \mathrm{~mm} / \mathrm{mm} 0,014 \mathrm{~mm} / \mathrm{mm}$; dan $0,016 \mathrm{~mm} / \mathrm{mm}$ dengan rasio regangan -1 . Pengujian pengaruh amplitudo regangan dan laju regangan pada paduan aluminium 7075-T7 memberikan representasi kecenderungan yang baik. Gambar 3 Variasi respon puncak tegangan tarik vs jumlah siklus pada amplitudo regangan yang berbeda dengan $\mathrm{R}=-1$ dapat dilihat pada. Gambar 3 memperlihatkan pelunakan siklik pada amplitudo regangan $=0,8 \%-1,6 \%$ Pelunakan siklik cenderung mengalami penurunan seiring meningkatnya regangan amplitude. Namun, pengerasan regangan terjadi pada regangan amplitude $0.4 \%$, seperti yang ditampilkan pada Gambar. 3.

Hasil penelitian menunjukkan bahwa amplitudo regangan memiliki pengaruh yang signifikan pada variasi puncak tegangan tarik vs jumlah siklus perilaku pelunakan/pengerasanpadun Al 7075-T7, bahwa amplitude regangan rendah $\left(\varepsilon_{\mathrm{a}}=\right.$ $0,6 \%$,) dapat menimbulkan efek pelunakan pada bahan dengan sifat ulet tertentu.

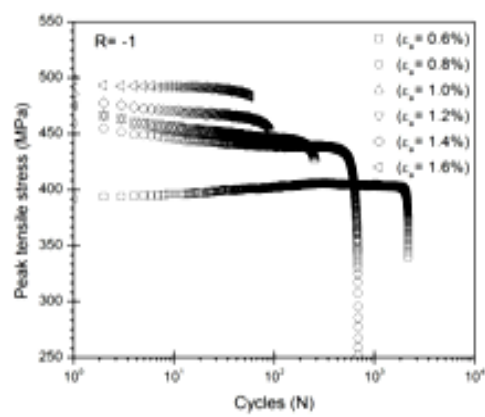

Gambar 3. Variasi respon puncak tegangan tarik vs jumlah siklus pada amplitudo regangan yang berbeda dengan $R=-1$.

Gambar 4A menunjukkan, menunjukan variasi respon puncak tegangan tarik vs jumlah siklus pada amplitudo regangan khas $0,5 \%$ dan $1,6 \%$ dengan rasio regangan dari rasio regangan -1 sampai 0.5 . Pelunakan siklik memperlihatkan perbedaan pada amplitudo regangan $0,5 \%$ dibandingkan dengan kasus regangan amplitude $0,6 \%$, pelunakan siklik lebih signifikan pada amplitudo regangan $0,5 \%$ dari rasio regangan -1 ke rasio regangan 0,05 ,. Respon puncak tegangan tarik yang berbeda dari 7075 paduan aluminium pada amplitudo regangan $0.5 \%$ dengan $\mathrm{R}=0.5$, dimana pada rasio regangan 0.5 bahan cenderung mengalami pengerasan. Sedangkan pada amplitude regangan $0.6 \%$, bahan cenderung mengalami pelunakan pada kondisi rasio regangan dari -1 sampai 0.5. Gambar 4B. Fenomena yang sama juga diamati oleh [Matsunaga dkk., 2014] pada bahan aluminium paduan.

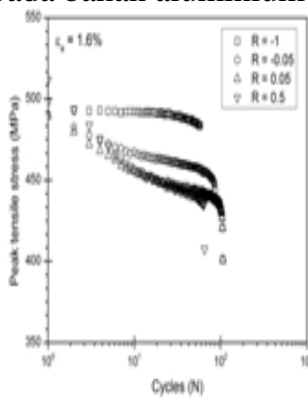

A

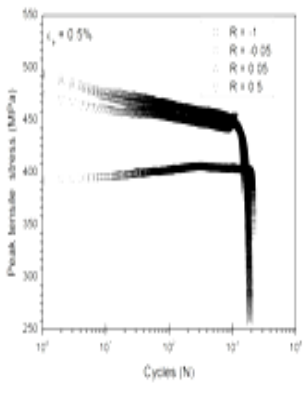

B

\section{Gambar 4. Menggambarkan variasi respon puncak tegangan tarikvs Jumlah siklus pada amplitudo regangan khas $0,6 \%$ dan $1,6 \%$}

Gambar 5 menampilkan variasi respon puncak tegangan tarik elastic dan plastic pada regangan -1 , yang disimbolkan dengan kotak untuk amplitudo regangan elastis, lingkaran untuk amplitude regangan plastis disimbolkan dan segitiga untuk amplitude regangan total dari tabel ini dapat kita lihat bahwa jika amplitude regangan elastis jauh 
lebih stabil dibanding dengan amplitude regangan plastis yang cenderung semakin turun dan lebih medekati softening yang sama halnya dengan amplitude regangan totalnya.

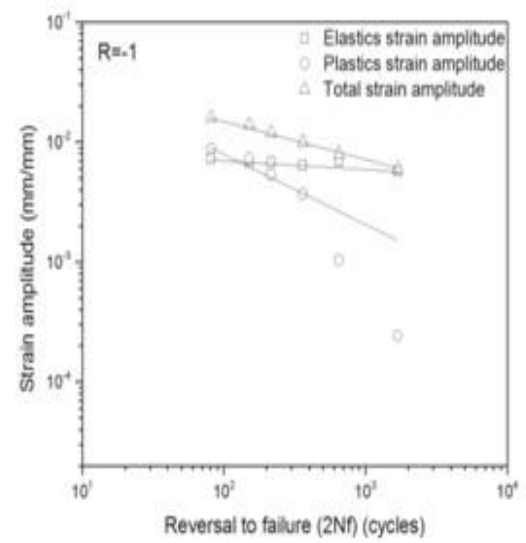

Gambar. 5 Mengaambarkan variasi respon puncak tegangan tarik elastic dan plastic pada $R=-1$

Sedangkan pada gambar 6. Menampilkan variasi respon puncak tegangan tarik maksimum elasticdan plastic yang disimbolkan dengan kotak untuk, untuk $\mathrm{R}=-1$ disimbolkan dengan lingkaran untuk $\mathrm{R}=-0,05$ disimbolkan dengan persegi empat, untuk $\mathrm{R}=0,05$ disimbolkan dengan segitiga, dan untuk rasio regangan 0,5 disimbolkan dengan segitiga terbalik, dari tabel ini dapat kita lihat bahwa jika pada $\mathrm{R}=-1$ mempunyai puncak tegangan tarik maksimum elastis dan plastic yang paling tinggi sedangkan pada $\mathrm{R}=-0,05$ dan 0,05puncak tegangan tarik maksimum elasticdan plastic cenderung sama sedangkan pada $\mathrm{R}=0.5$ mempunyai puncak tegangan tarik maksimum elastis dan plastis yang paling rendah.

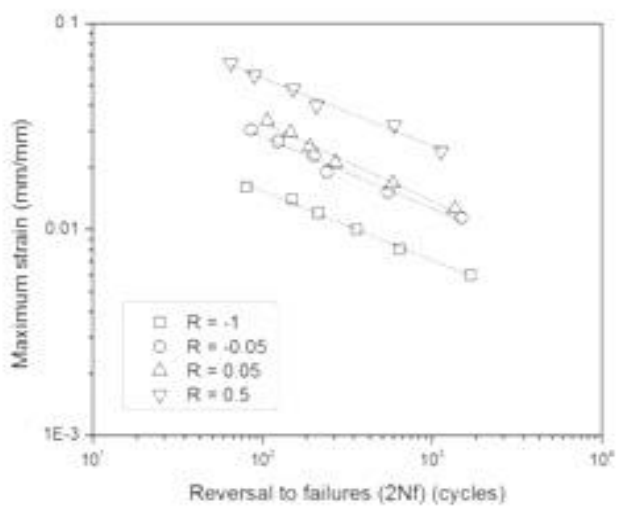

Gambar. 6. Variasi respon puncak regangan tarik maksimum terhadap jumlah siklus patah
Variasi respon puncak tegangan tarik vs jumlah siklus di bawah $\mathrm{R}=-1,-0.05,0,05$ dan 0,5 : (a) $\varepsilon a 0.6 \%$ dan (b) $\varepsilon_{a} 1.6 \%$ adalah puncak tegangan tarik pada siklus pertama dan setengah dari umur kelelahan, masing-masing.

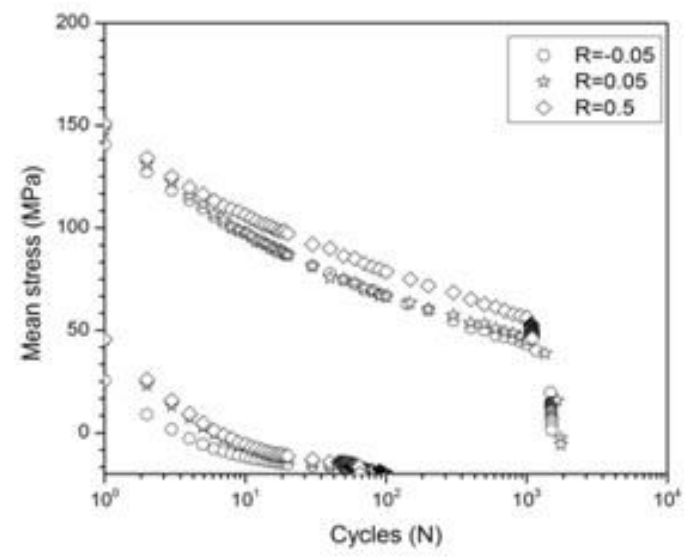

Gambar. 7. Variasi respon tegangan rata-rata terhadap jumlah siklus pada amplitude regangan $(a) \varepsilon_{a}=0.6 \%$ dan (b) $\varepsilon_{a}=1.6 \%$

Hasil perilaku softening dan hardening pada (R) -1 dan amplitudo regangan berbeda secara lengkap diberikan.Rasio pelunakan diperlihatkan pada amplitudo regangan dan rasio ketegangan yang berbeda digambarkan dalam Gambar 8, rasio pelunakan siklik diplot sebagai fungsi dari amplitudo regangan. Nilai pada gambar grafik ini menunjukkan bahwa tingkat pelunakan siklik menurun secara linier dengan meningkatnya amplitudo regangan diterapkan. Ketika amplitudo regangan meningkat menjadi $0.5 \%$,rasio pelunakan siklik adalah mendekati nol, menandakan fakta bahwa pelunakan siklik hampir tidak ada. Pada Gambar.8, rasio pelunakan siklik diplot sebagai fungsi dari rasio regangan diterapkan pada amplitudo regangan khas $1 \%$ dan $0,5 \%$. bahwa dengan meningkatnya Rasio regangan maka tingkat pelunakan siklik meningkat secara linear di dua amplitudo regangan.Hal ini dapat diamati pada Gambar. 8 bahwa perilaku puncak tegangan tarik tergantung pada amplitudo regangan yang diterapkan. Semakin besar amplitudo regangan, semakin besar tingkat rata relaksasi stres. dan kesimpulan, pelunakan siklik dari 7075-T7 paduan aluminium tergantung pada kedua amplitudo regangan dan rasio regangan. Tingkat pelunakan siklik materi meningkat secara linear dengan amplitudo regangan menurun dan meningkatnya rasio regangan. 


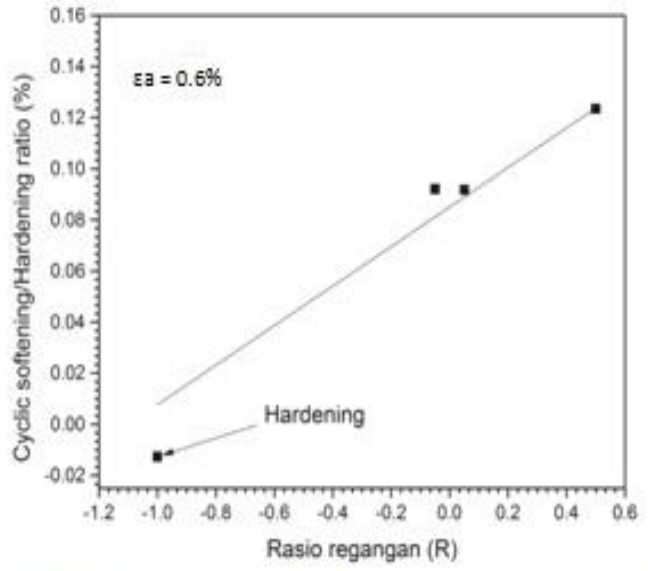

Gambar. 8. Pengaruh pelunakan dan pengerasan Al 7075-T7 pada amplitude repangan $0.6 \%$ dengan rasio regangan yang berbeda.

\section{Karakterisasi Struktur mikro}

Strain rate berhubungan erat dengan retak yang terjadi saat kelelahan, retakan utama terus menerus menyebar seperti terlihat pada gambar 6 . Sementara itu silikon tampak lebih cenderung ditembus oleh retakan utama partikel silikon yang disebapkan regangan elastis di bawah kondisi pembebanan siklik. Fenomena retak yang terjadi pada material disebapkan pengaruh strain rate amplitudo regangan yang menyebapkan terjadinya kelelahan, Pada gambar 9. menunjukan dimana sebelum terjadinya fase presipitasi diawali dengan batas butir kemudian mengalami fase presipitasi lalu terjadi perambatan retak yang mengakibatkan cabang retak yang semakin melebar.

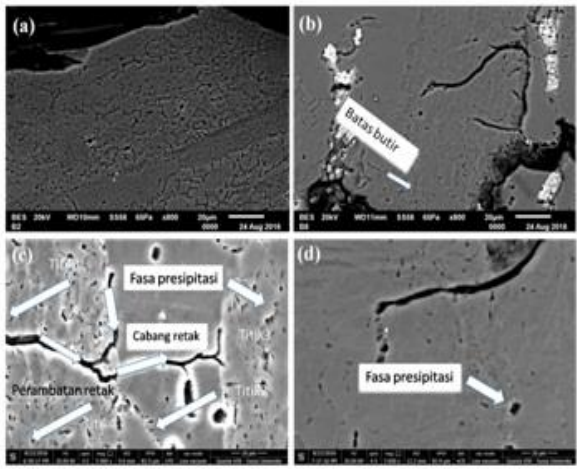

Gambar 9. SEM struktur mikro dan perambatan retak spesimen hasil uji LCF dengan a. $R=-1, b . R=-0.05, c . R=$ 0.05 , dan $\mathrm{d} . \mathrm{R}=0.5$

Struktur mikro spesimen setelah uji LCF diobservasi pada daerah patahan dan daerah sekitar patahan menggunakan SEM. Sedangkan uji komposisi elemen (at.\%) dilakukan dengan EDS analisis spektrum.
Pada gambar 10a. kondisi dimana material mengalami langsung patah tanpa mengalami proses perambatan retak, sedangkan pada gambar $10 \mathrm{~b}$ arah retakannya mengikuti alur retaknya dan terjadi juga dimana retak patah pada 2 bidangnya, pada gambar 10c hanya terjadi yaitu patah pada bagian cekungan ductile, pada gambar 10 terjadi dimple crack, crack slip plane, dan sub crack retak pada cabang utama.

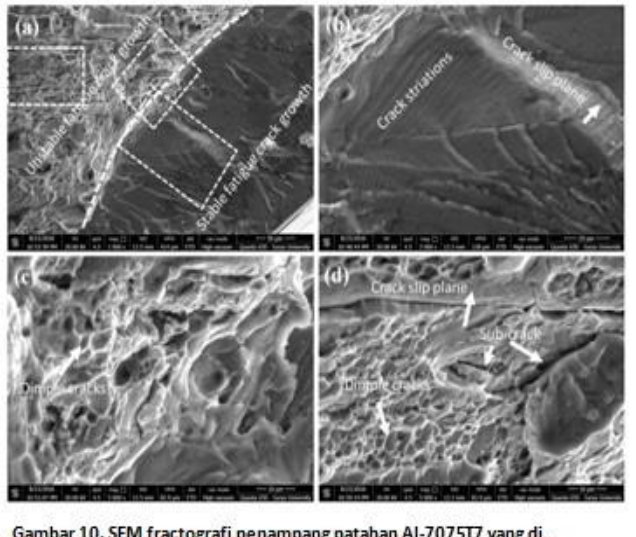

Gambar 10. SEM fractografi penampang patahan Al-7075T7 yang di uji LCF.

\section{Ketahanan terhadap tegangan tarik}

Kurva beban monotonik dan siklik. Hubungan antara tegangan dan regangan hasil uji tarik (monotonik) diplot pada gambar 11. Selain itu hubungan antara amplitudo tegangan dengan regangan amplitudo pada laju regangan (strain rate) hasil uji beban siklik (LCF) yang berbeda juga diplot pada gambar 11 .

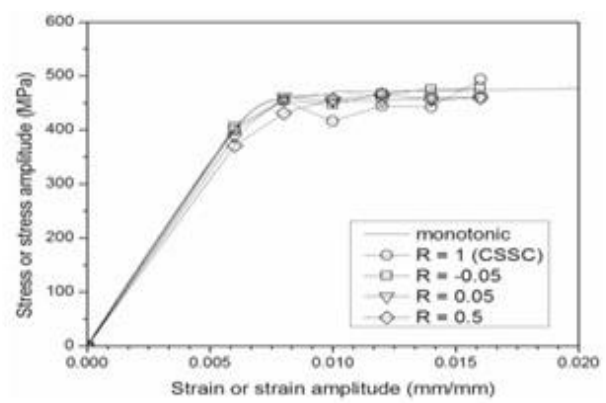

Gambar 11. Kurva tegangan vs regangan paduan AI 7075-T7 pada kondisi uii tarik statis dan siklik

Kurva regangan tegangan siklik diperoleh dengan menghubungkan titik puncak loop histeresis stabil untuk amplitudo strain yang berbeda. Kurva regangan tegangan siklik di bawah empat rasio regangan dibandingkan dengan kurva ketegangan monotonik untuk paduan Al 7075-T7. Perilaku tarik 
monotonic dari paduan aluminium menunjukkan penurunan dimana kurva ini menunjukkan regangan dan tegangan untuk kondisi siklik dan monotonic untuk monotonic disimbolkan dengan garis, untuk rasio regangan $=-1$ disimbolkan dengan lingkaran untuk rasio regangan $=-0,05$ disimbolkan dengan persegi empat, untuk rasio regangan $=0,05$ disimbolkan dengan segitiga, dan untuk rasio regangan $=0,5$ disimbolkan dengan kotak, dari tabel ini dapat kita lihat bahwa jika rasio regangannya positif maka tegangan amplitudonya cenderung dibawah tegangan monotoniknya sedangkan jika rasio regangannya negative maka tegangan amplitudonya diatas tegangan monotonicknya.

Hal ini disebabkan adanya efek bousinger dimana untuk semua rasio regangannya itu kondisi umumnya adalah tarik tekan dan tekan tarik (cscs). Dimana K' adalah koefisien kekuatan siklis dan n' adalah eksponen pengerasan regangan siklik. Parameter karakteristik siklik K' dan n' untuk rasio regangan yang berbeda diperoleh dari analisis regresi linier log-log dengan amplitudo strain plastik dan amplitudo tegangan kerja pada paruh waktu. Ketergantungan yang kuat dari parameter karakteristik siklik K'dan n' pada rasio regangan yang dikenakan juga dilaporkan pada paduan aluminium lainnya, seperti campuran. Pelunakan siklik dari paduan Al 7075-T7 paduan aluminium tergantung pada kedua amplitudo regangan dan rasio regangan. Tingkat pelunakan siklik meningkat secara linear dengan amplitudo regangan menurun dan meningkatnya rasio regangan.

\section{Kelelahan siklus rendah (LCF) berbasis pendekatan coffinmansion}

Pemodelan pendekatan berbasis regangan sering digunakan dalam aplikasi Low Cycle Fatigue di mana secara akurat dapat melihat sifat plastisitas yang menghindarkan kerusakan keausan dalam daerah ini. Koefisien umur kelelahan dan eksponenumur kelelahan pada persamaan diperoleh dengan menentukan persamaan regresi yang terbentukoleh masing-masing kurva. Harga-harga koefisien dan eksponen umur kelelahan untuk tiap material yang diujiditabelkan pada tabel 2 . Berdasarkan data-data dari tabel 2, model matematika untuk prediksi perilaku sifat fatik siklus rendah dengan rasio teganga, $\mathrm{R}=-1$ pada penguajian dengan amplitude regangan $0.6 \%-1.6 \%$ diperoleh persamaaan (1), sebagai berikut:

$$
\begin{aligned}
& \frac{\Delta \varepsilon}{2}=\frac{\sigma^{\prime} f}{E}\left(2 N_{f}\right)^{b}+\varepsilon_{f}^{\prime}\left(2 N_{f}\right)^{c} \\
& \frac{\Delta \varepsilon}{2}=\frac{\sigma^{\prime} f}{E}\left(2 N_{f}\right)^{b} \\
& \frac{\Delta \varepsilon}{2}=\frac{763.10}{E}(763.10)^{-0.0756}+(763.10)^{-0.624}
\end{aligned}
$$

\begin{tabular}{lc}
\hline$R-1$ \\
\hline Fatigue strength coefficient, $\sigma_{f}^{\prime}(\mathrm{Mpg})$ & 763.10 \\
\hline Fatigue strength exponant, $b$ & -0.0756 \\
\hline Fatigue keuletan coefficient, $\varepsilon_{f}^{\prime}(\mathrm{mm} / \mathrm{mm})$ & 0.231 \\
\hline Fatigue keuletan exponent, $\mathrm{c}$ & -0.624 \\
\hline
\end{tabular}

Tabel 2. Sifat fatik siklus rendahpaduan A1 7075-T7 padapengujian $R=-1$

\section{SIMPULAN}

Pada pengujian ini, laju regangan untuk uji kelelahan siklus rendah pada laju regangan konstan $($ Strain rate $)=4 \times 10^{-3} / \mathrm{s}$ paduan Al7075-T7 secara sistematis diamati dalam rasio regangan $(\mathrm{R})=-1$, $0.05,0.05$, dan 0.5 . Untuk setiap rasio regangan diberikanamplitudo regangan $=0.006 \mathrm{~mm} / \mathrm{mm}$, $0.008 \mathrm{~mm} / \mathrm{mm}, 0.010 \mathrm{~mm} / \mathrm{mm}, 0.012 \mathrm{~mm} / \mathrm{mm}, 0.014$ $\mathrm{mm} / \mathrm{mm}$ dan $0.016 \mathrm{~mm} / \mathrm{mm}$. Paduan aluminium menunjukkan stabilitas yang kontinyuuntuk siklus kegagalan, umur material (fatique life) yang tertinggi didapatkan pada rasio regangan $=0.05$ dengan amplitudo regangan $=0.016 \mathrm{~mm} / \mathrm{mm}$ sedangkan umur (fatique life) terendah yaitu pada laju regangan $=-0.05 \mathrm{~mm} / \mathrm{mm}$ dengan amplitudo regangan $=0.006$ $\mathrm{mm} / \mathrm{mm}$, di mana material menunjukan pengerasan siklik terus menerus dari siklus pertama sampai gagal. Fenomena yang diamati dalam loop histeresis tren yang baik dengandeformasi siklik (pengerasan atau stabilitas). Frakturpermukaan untuk paduan $\mathrm{Al}$ 7075-T7 menunjukkan beberapa crack strations, retak cekung pada bidang slip, dan retak kedua yang merupakan cabang retak utama.

\section{REKOMENDASI}

Dari penelitian yang telah dilakukan, rekomendasi yang dapat diberikan adalah: (1) Perlu dilakukan penelitian lebih lanjut tentang sistem siklus fatik tingi (HCF) dari Al 7075 T7. (2) Untuk pemilihan amplitudo regangan diupayakan di bawah $0.015 \mathrm{~mm} / \mathrm{mm}$.

\section{DAFTAR PUSTAKA}

[1] Agarwal H., Gokhale A.M., Graham S., Horstemeyer M.F. Pertumbuhan Void di 6061-aluminium campuran bawah negara stres triaksial, Material Science and Engineering 2003; A341: 35-42.

[2] Angeloni M., 2013, Fatigue life evaluation of A356 aluminum alloy used for engine cylinder head. 
[3] ASTM E8, 2004, Standard Test Methods for Tension Testing of Metallic Materials, West Conshohocken, United States. ASTM E606, 2004, Standard Practice for Strain.

[4] Brammer A.T., 2013, Experiments and modeling of the effects of heatexposure on fatigue of 6061 and 7075 aluminium alloys.

[5] Fan K.L., He G.Q., et.al., 2013, Tensile and fatigue properties of gravity casting aluminum alloys for engine cylinder heads, Materials Science and Engineering: A, 586: 78-85.

[6] Fonte M.D., Reis L., Freitas M.D, 2015, Fatigue crack growth under rotating bending loading on aluminium alloy 7075-T6 and the effect of a steady torsion, Theoretical and Applied Fracture Mechanics, 80, Part A: $57-$ 64.

[7] Joshi T.C., Prakash U., Dabhade V.V., 2015, Microstructural development during hot forging of Al 7075 powder, Journal of Alloys and Compounds, 639: 123-130.

[8] Matsunaga H., Makizaki M., Socie D.F., Yanase K., Endo M., 2014, Acceleration of fatigue crack growth due to occasional mode II loading in 7075 aluminum alloy, Engineering Fracture Mechanics, 123: 126136.

[9] Song M.S., Kong Y.Y., et.al., 2011, Cyclic stress-strain behavior and low cycle fatigue life of cast A356 alloys, International Journal of Fatigue, 33(12): 1600-1607.

[10] Torabi A.R., Alaei M., 2015, Mixed-mode ductile failure analysis of V-notched Al 7075T6 thin sheets, Engineering Fracture Mechanics, 150: 70-95.

[11] Tschegg S.E.S.,Meischel M., Arcari A., Iyyer N., Apetre N., Phan N., 2016, Combined cycle fatigue of 7075 aluminum alloy Fracture surface characterization and short crack propagation, International Journalof Fatigue,doi:10.1016/j.ijfatigue.2015.10.022.

[12] Yamada H., Tsurudome M., Miura N., Horikawa K., Ogasawara N., 2015, Keuletan loss of 7075 aluminum alloys affected by interaction of hydrogen, fatigue deformation, and strain rate, Materials Science and Engineering: A, 642: 194-203. Journal of Fatigue,33(12) : 1600-1607.
[13] Zhu X., Shyam A., et.al., 2006, Effects of microstructure and temperature on fatigue behavior of E319-T7 cast aluminum alloy in very long life cycles, International Journal of Fatigue, 28(11): 1566-1571. 